\title{
What do financial intermediaries do?
}

\author{
Franklin Allen ${ }^{\mathrm{a}, *}$, Anthony M. Santomero ${ }^{\mathrm{b}}$ \\ ${ }^{a}$ The Wharton School, University of Pennsylvania, Room 2336, Steinberg Hall-Dietrich Hall, \\ Philadelphia, PA 19104-6367, USA \\ ${ }^{\mathrm{b}}$ Federal Reserve Bank of Philadelphia, Philadelphia, PA 19106, USA
}

Received 29 July 1999; accepted 13 September 1999

\begin{abstract}
This paper presents evidence that the traditional banking business of accepting deposits and making loans has declined significantly in the US in recent years. There has been a switch from directly held assets to pension funds and mutual funds. However, banks have maintained their position relative to GDP by innovating and switching from their traditional business to fee-producing activities. A comparison of investor portfolios across countries shows that households in the US and UK bear considerably more risk from their investments than counterparts in Japan, France and Germany. It is argued that in these latter countries intermediaries can manage risk by holding liquid reserves and intertemporally smoothing. However, in the US and UK competition from financial markets prevents this and risk management must be accomplished using derivatives and other similar techniques. The decline in the traditional banking business and the financial innovation undertaken by banks in the US is interpreted as a response to the competition from markets and the decline of intertemporal smoothing. (C) 2001 Elsevier Science B.V. All rights reserved.
\end{abstract}

JEL classification: G2; G1; E5; L2

Keywords: Intermediation; Risk management; Delegated monitoring; Banks; Participation costs

\footnotetext{
${ }^{*}$ Corresponding author. Tel.: +1-215-898-3629; fax: 1-215-573-2207.

E-mail address: allenf@wharton.upenn.edu (F. Allen).
} 


\section{Introduction}

Traditionally, transaction costs and asymmetric information have provided the foundation for understanding intermediaries. The emergence of intermediaries resulting from such imperfections in the capital market has been formalized in the contributions of Dewatripont and Tirole (1994) and Freixas and Rochet (1997). In fact, the two major reviews of intermediation theory, Santomero (1984) and Bhattacharya and Thakor (1993) illustrate how central such imperfections are to the intermediation literature of the past two decades. The apparent implication of this view is that, if these frictions are reduced, intermediaries will become less important.

There has been a significant reduction in transaction costs and asymmetric information in recent decades. Over this same period, the importance of traditional banks that take deposits and make loans has, by some measures, been reduced. However, other forms of intermediaries such as pension funds and mutual funds have grown significantly. In addition, new financial markets such as financial futures and options have developed, as markets for intermediaries rather than for individuals. All of this seems, if not contrary to standard theory, at least inconsistent with it.

In Allen and Santomero (1997) (henceforth AS) we suggest that this is because the recent focus of intermediation theory has been too narrow. We argue that understanding these changes requires different theories of intermediation that stress risk trading, risk management and participation costs as the key reasons for the existence of modern intermediaries.

Our contribution has caused quite a firestorm, with a significant number of citations, discussions and debates. Recently a paper by Scholtens and van Wensveen (1999) (SW) raised a number of important issues concerning our analysis and we will take this opportunity to more fully develop our perspective on the evolution of intermediation and the theory that purports to explain it. We choose to use this as a point of departure because their contribution raises three key issues that warrant further discussion, which will add to our understanding of the evolution of specific institutions within the financial market.

First, it is pointed out that while it is true that the share of assets of traditional commercial banks has shrunk relative to other intermediaries in the US, it is also the case that relative to GDP banks' assets have increased. Clearly, banking is not disappearing. Second, they question whether risk management is a new phenomenon. They mirror a view that argues that banks have always been in the risk management business, suggesting that the origins of banking and insurance lie in their risk transforming and management functions. Although the precise way in which risk is managed may have changed, intermediaries have always been engaged in risk management, broadly defined. Third, they suggest that the theory of financial intermediation needs to have an understanding of the dynamic process of financial innovation 
to adequately address the transformation of the financial sector that is currently taking place globally.

In this paper we use these observations as a starting point for considering what it is that financial intermediaries do. At the center, of course, financial systems perform the function of reallocating the resources of economic units with surplus funds (savers) to economic units with funding needs (borrowers). Our interest, however, is how and why this role varies across time and across countries. We will approach this question by comparing the role of intermediaries and their relationship to markets at different dates in a set of relevant countries, including the US, UK, France, Germany and Japan.

We will also contrast and compare our results to those in an important study by Schmidt et al. (1999). In this work, the authors have considered the issue of whether banks have been losing importance relative to markets in France, Germany and the UK. They find that there is neither a general trend from intermediaries to markets, nor a decline in the importance of banks in Germany or the UK. In France, there are signs of a decline in banks and a move towards markets. However, and importantly, there is a change in the length of intermediation chains in all three systems.

We develop our argument as follows. Section 2 considers a range of appropriate measures for how the financial system has changed through time in the US. Most of these suggest that the role of banks in their traditional businesses has declined. However, banks have been entrepreneurial and in many cases have changed their activities so that, by some measures, they have maintained their position.

In Section 3 we consider whether the way in which intermediaries manage risk differs across different countries by looking at the portfolios of assets ultimately held by households in each country. In the US and UK, households hold a large proportion of risky assets, such as equity, and bear considerable risk. However, in Japan, France and Germany, they mostly hold their assets in safe instruments, such as bank accounts and fixed-income securities, and therefore hold very few risky assets. How can the risk borne by households differ so much across countries?

Using the framework of Allen and Gale (1997, 1999a) we suggest that there is a fundamental difference in the way that intermediaries in the two sets of countries manage risk. In Japan, France and Germany competition from financial markets has been muted, and as a result intermediaries are able to manage risk through intertemporal smoothing. This involves building up reserves in safe low yielding assets when returns are high. When returns are low the intermediaries can draw on these reserves and shield their customers from risk. However, when there is significant competition from financial markets, as in the US and UK in recent years, intertemporal smoothing is no longer possible. Households will withdraw their funds from banks that try to build up reserves and use them to buy other assets that allow the households to consume 
all the current payoffs. In this case it will not be possible for banks to manage risk through the accumulation and depletion of reserves. Instead, they must use derivatives and other similar techniques for managing risk.

Section 4 considers how the transformation of the US banking system documented in Section 2 can be understood using the framework developed in Section 3. We suggest that, before the surge in financial innovation in the last 25 years in the US, intermediaries such as banks were able to manage risk through intertemporal smoothing. However, as financial markets became increasingly more competitive, banks were forced to move away from using intertemporal smoothing as their main risk management technique. Instead, they were forced to develop alternative ways of managing risk that did not involve holding large amounts of funds in low yielding safe assets. These techniques involved using instruments such as options and swaps and dynamic trading strategies. As traditional banking businesses began to dry up, the management of those institutions was forced to become entrepreneurial and develop new businesses in order to survive. Some of these new businesses involved catering to the demand for new risk management services associated with the growing need of their customers to deal with the risks previously absorbed by the intermediaries themselves. In short, the evolution of intermediaries is part and parcel of the evolution and competition that is accelerating in the markets they serve.

Finally, Section 5 contains a summary of our view and raises some puzzles that remain unanswered in our attempt to understand differences in financial systems. Many of these appear to be measurement issues, but they mask substantive issues and gaps in our knowledge of this important area of inquiry.

\section{Measuring differences in financial systems}

As is widely acknowledged US depository institutions have had a falling share of the financial assets of intermediaries for many years. Scholtens and van Wensveen (1999) use Fig. 1 to illustrate this point. Although this declining share is often assumed to be a recent phenomenon, in fact the trend has been apparent since the 1920s, as shown in Fig. 2. Indeed, the 1920s was an era much like the last two decades, in which the share of assets held by banks declined and proportion of financial assets held in the form of pension funds, trusts and investment companies grew. In the broader historical context the anomaly may have been the relative stability of the bank share of total assets from the 1940s through to the mid-1970s.

However, Scholtens and van Wensveen (1999) also observe that relative to total financial assets as a percentage of GDP the assets in the banking sector have not declined markedly. The diagram they use to illustrate this point is given here as Fig. 3. 


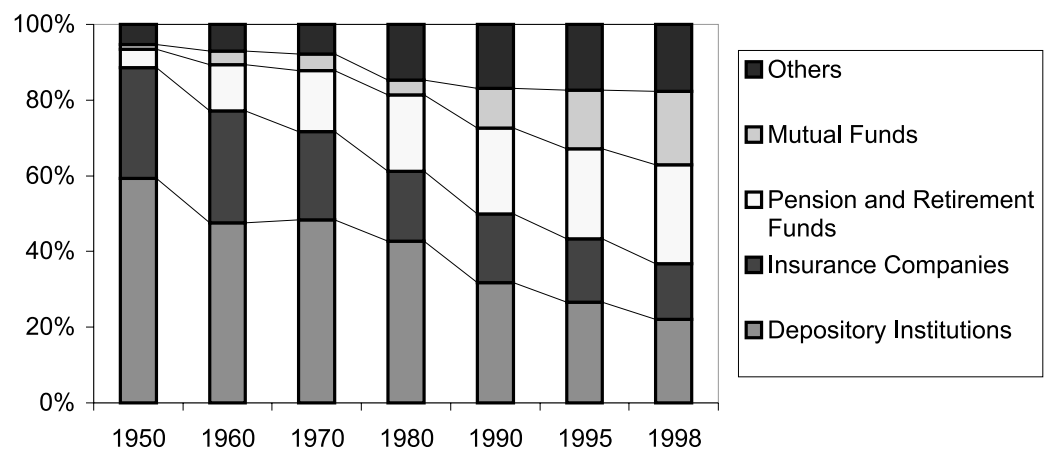

Fig. 1. Distribution of US financial assets by the main types of financial intermediaries (Source: Barth et al., 1997, and updated tables from Barth).

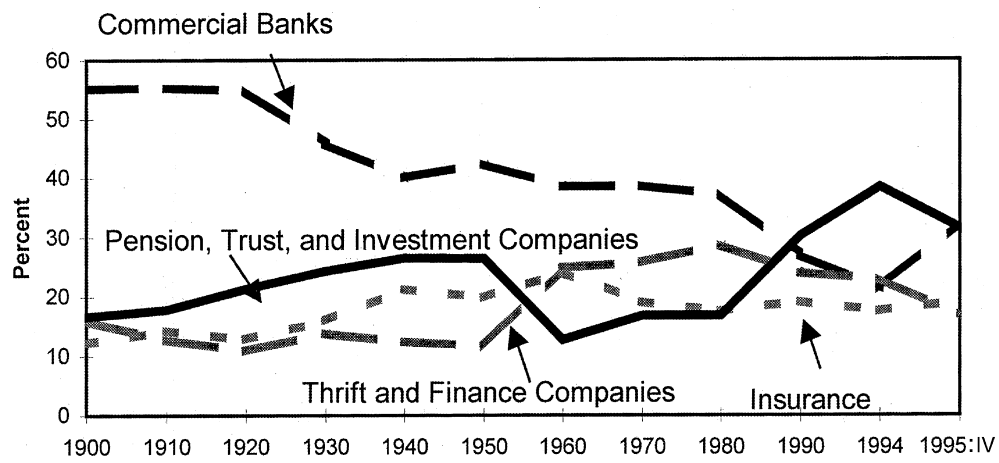

Fig. 2. Relative shares of total financial intermediary assets, 1900-1995:IV (Source: Federal Reserve Bulletin).

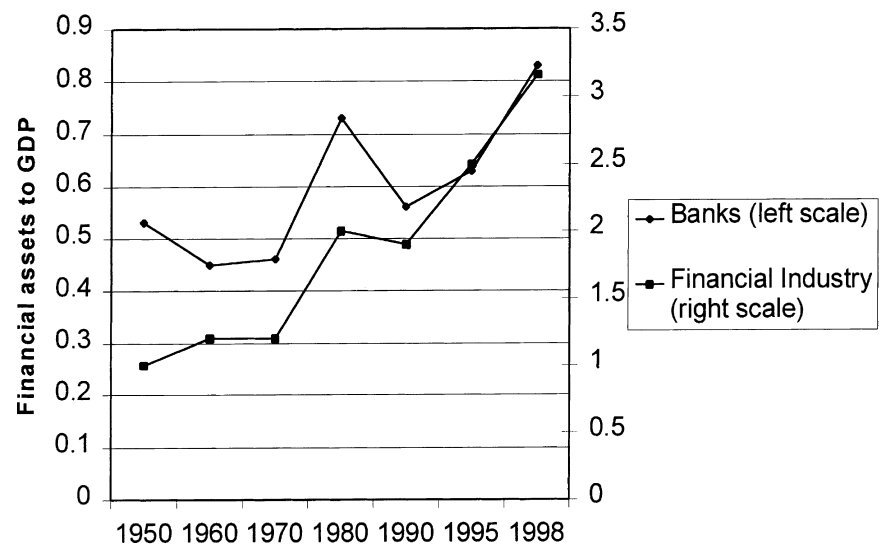

Fig. 3. Relative size of the US financial sector and the banking industry (Source: Barth et al., 1997, and updated tables from Barth). 


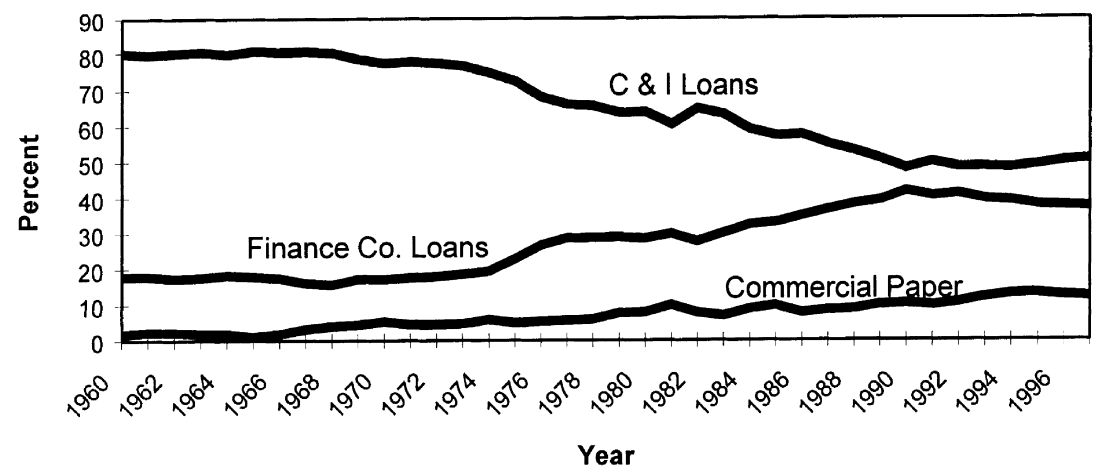

Fig. 4. The decline in the role of banks as intermediators of credit risk (Source: Board of Governor of the Federal Reserve System, "Flow of Funds Accounts", 1998).

How can these data be reconciled with the data shown in Fig. 1, where it is clear that banks are losing ground relative to other intermediaries? The answer lies in recognizing that financial assets can be divided into three mutually exclusive subsets. The first is those held by banks or more properly depository institutions; the second is those held by nonbank intermediaries such as pension funds and mutual funds; and the third is those that are directly held assets, such as stocks and bonds. If banks are shrinking relative to other intermediaries, but are stable relative to total financial assets then this implies that there is a switch from directly held assets to nonbank intermediaries. This is consistent with the long-term trend of the decline in the individual ownership of corporate equity which was documented in AS.

The evidence presented in Figs. 1-3 is not the only way to measure how the financial system is changing. Other changes have taken place in the US banking system which are often associated with the widespread view that banks are becoming less important. The decline in the role of banks as intermediators of credit risk has been most pronounced in a US context with regard to business finance as Fig. 4 indicates. Banks have lost ground to other intermediaries such as finance companies and to securities markets, especially the commercial paper and high yield securities market.

The decline in business lending is also mirrored in consumer lending as shown in Fig. 5. Banks have lost market share to nonbanks such as AT\&T, GMAC, GE and Morgan Stanley Dean Witter. Twenty years ago, banks completely dominated the entire credit card business. Now, banks hold no more than $25 \%$ of receivables, and close to $80 \%$ of credit card transactions are processed by nonbanks such as First Data Resources. ${ }^{1}$

\footnotetext{
${ }^{1}$ See Business Week, 12 June 1995, p. 70.
} 


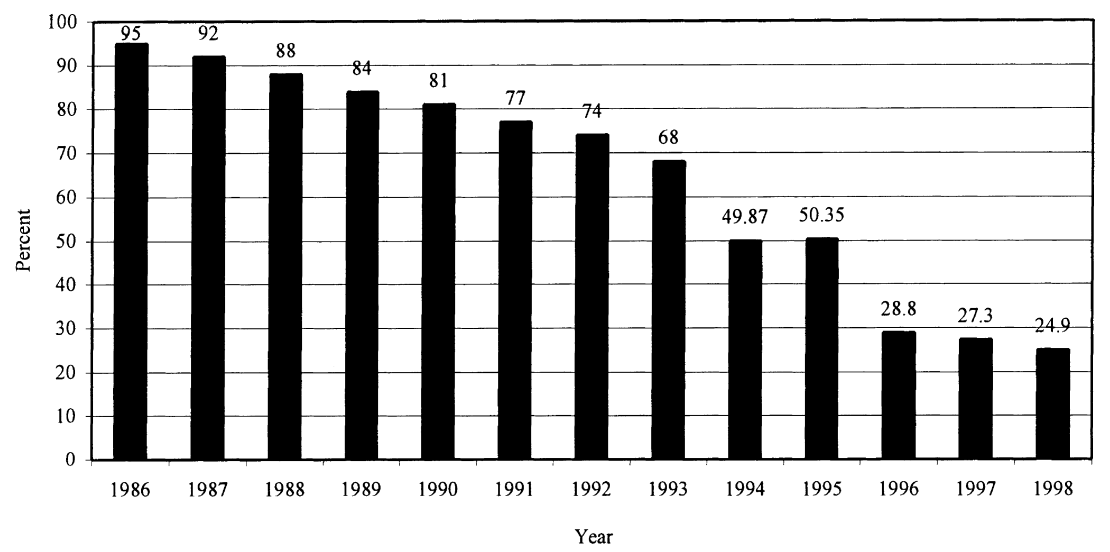

Fig. 5. Bank market share of credit card receivables, 1986-1998 (Source: Faulkner and Gray's Card Industry Directory, various years).

Increasingly, single-purpose providers have successfully competed for some of the most profitable traditional bank products provided by full service banking institutions. In addition, the development of securitization techniques has transformed the way in which many kinds of credit transactions - which would previously have been conventional bank loans - are structured.

The growing importance of securitization is especially obvious in the transformation of the traditional mortgage as shown in Fig. 6. Formerly, a bank originated, funded and serviced the mortgage until it was repaid. Now, one firm may originate the mortgage. Another firm may fund the mortgage, or pool the mortgage with others and partition the anticipated flow of income

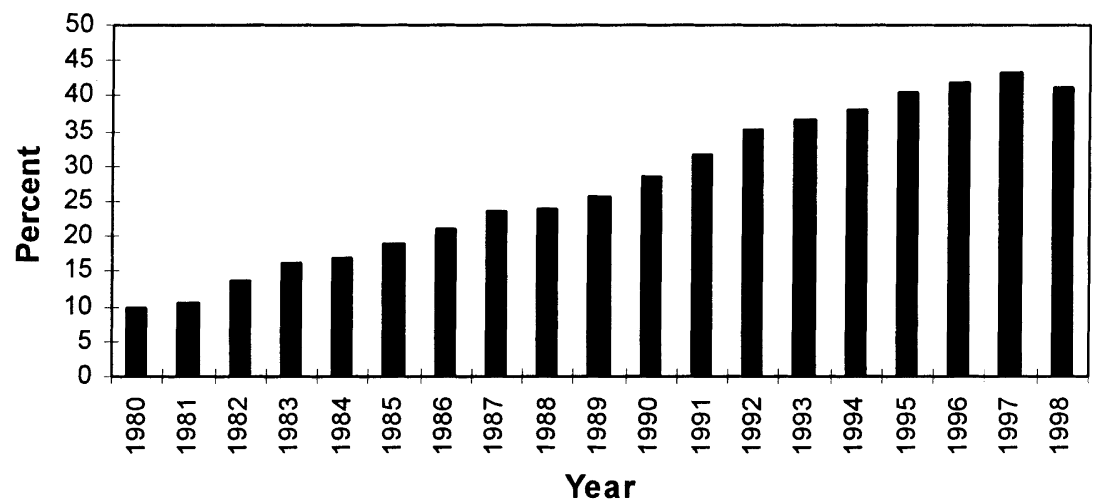

Fig. 6. Securitized mortgages as a pecent of total mortgages, 1980-1998 (Source: Board of Governors of the Federal Reserve System, "Flow of Funds Accounts", various years). 
from the pool into marketable securities that will appeal to particular groups of investors around the world. Another firm may insure the pool of mortgages to facilitate this process. The servicing of the mortgage may be allocated to yet another specialist firm that has data processing expertise. The consequence is that mortgages will be funded at lower cost than if an intermediary were obliged to hold mortgages to maturity and what was once an illiquid bank asset is transformed into a highly marketable security. This unbundling can be executed so smoothly that the mortgagee may be entirely unaware that it has taken place.

These techniques have been successfully applied to many other kinds of credit transactions, including credit card receivables, auto loans, and small business loans. And, the trend has now reached the standard commercial loan, with the advent of and growth in the emerging CLO, collateralized loan obligation, market.

Banks are also losing ground on the liability side of their balance sheets. As the baby boom generation matures, and inherits or accumulates wealth, consumer demand is shifting from credit products to savings products. This trend is apparent in most industrial countries, but is somewhat further along in the US because of the demographics associated with the post-war, "Baby Boom" generation. In the US, over the next 20 years the population under age 50 will remain the same as it is today, but the population older than 50 will double. For the latter group, asset accumulation in anticipation of retirement is of tantamount importance and it has made this market the fastest segment of household wealth accumulation. The traditional bank entry in the competition for consumer savings - the time and savings account - is deservedly losing ground here to mutual funds that have much leaner cost structures and can offer significantly higher returns. Accordingly, bank time and savings deposits have declined steadily relative to fixed-income mutual funds since 1980 as shown in Fig. 7. ${ }^{2}$

New technology - often introduced by nonbanks - is jeopardizing even the fundamental role of banks in facilitating payments. Many mutual fund families and most brokerage houses offer cash management accounts that permit individuals to arrange for their salaries to be automatically deposited in their cash management accounts from which routine payments can be made automatically and irregular payments may be made by check or phone 24 hours a day. Personal checks may be routinely drawn on the money market account. In addition, money market accounts can be linked to a credit card that also functions as a debit card at automated teller machines for cash needs. Although payments through the account are cleared through a bank, the role of

\footnotetext{
${ }^{2}$ See Santomero and Hoffman (1998) for even more evidence of this trend away from banking institutions.
} 


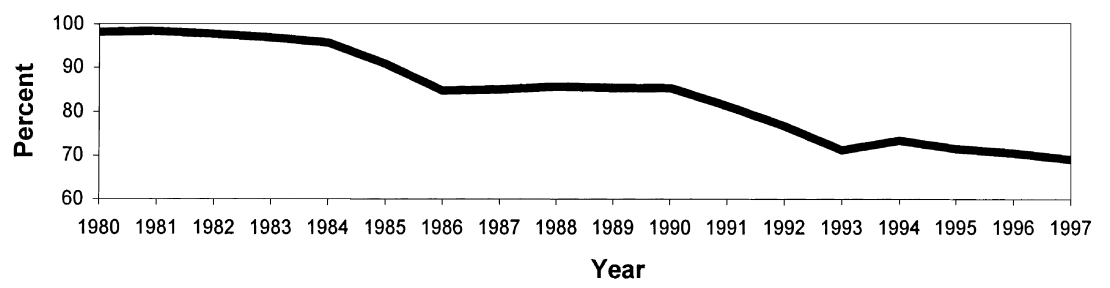

Fig. 7. Bank time and savings deposits decline relative to fixed-income mutual funds, 1980-1997 (Source: Investment Company Institute Mutual Fund Fact Book, 1998; and Federal Deposit Insurance Company, Historical Statistics on Banking, 1997).

the bank is a regulatory artifact, not an essential part of the transaction or the deposit type relationship between the intermediary and its customer.

America's love affair with credit cards has also eroded a central role of demand deposits in the payment system. With some 500 million credit cards outstanding, ${ }^{3}$ the number of transactions using credit cards continues to rise, approaching 17 trillion by $1997 .{ }^{4}$ These payment vehicles are now issued primarily by monoline organizations or distributed nationally by mass mailing. This is quite different than the usual multi-product banking relationship and serves to further erode the previously unique role of the local bank and its deposit products. The continued expansion of e-commerce suggests that this type of vehicle will become even more important over time for transaction purposes than the traditional demand deposit and the paper check. The net result of all this is that the relative importance of checkable deposits is declining, as are balances held in this form; see Fig. 8.

In view of the declining role of the traditional intermediation business, it is not surprising to see that the importance of net interest income to both the banking sector and the economy as a whole has fallen in the US as shown in Fig. 9. Because this decline in the basic intermediation business is economically motivated and technologically driven, it is also likely to be irreversible.

Although the intermediation business has declined, banks have managed to prosper nonetheless, by shifting from traditional intermediation functions to fee-producing activities such as trusts, annuities, mutual funds, mortgage banking, insurance brokerage and transactions services. Fig. 10 shows how noninterest income has risen relative to financial sector GDP. Notwithstanding the constraints on allowable bank activities in the US, imposed by the GlassSteagall Act and the Bank Holding Company Act, banks have managed to develop new lines of business to compensate for the decline in the traditional intermediation business.

\footnotetext{
${ }^{3}$ BIS (1998), Table 7.

${ }^{4}$ BIS (1998), Table 12.
} 


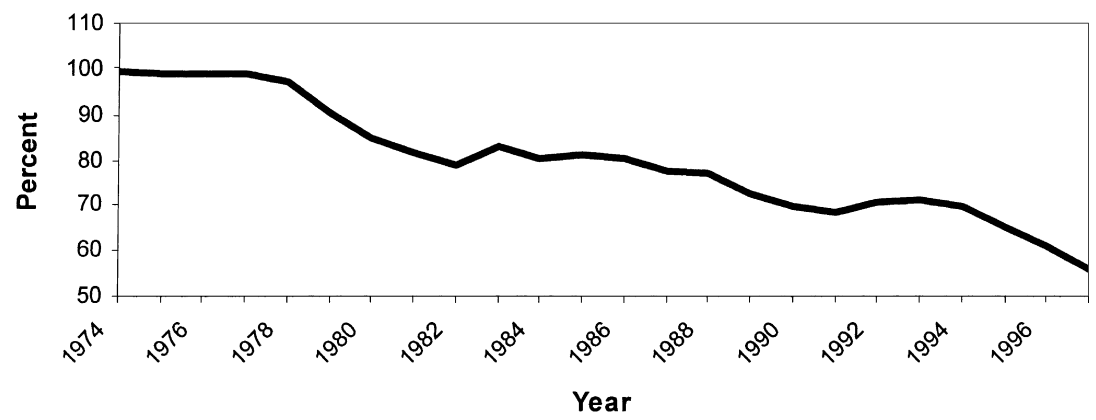

Fig. 8. Checkable deposits decline relative to money market mutual fund shares, 1974-1998 (Source: Investment Company Institute Mutual Fund Fact Book, 1998; and Federal Deposit Insurance Company, Historical Statistics on Banking, 1997).

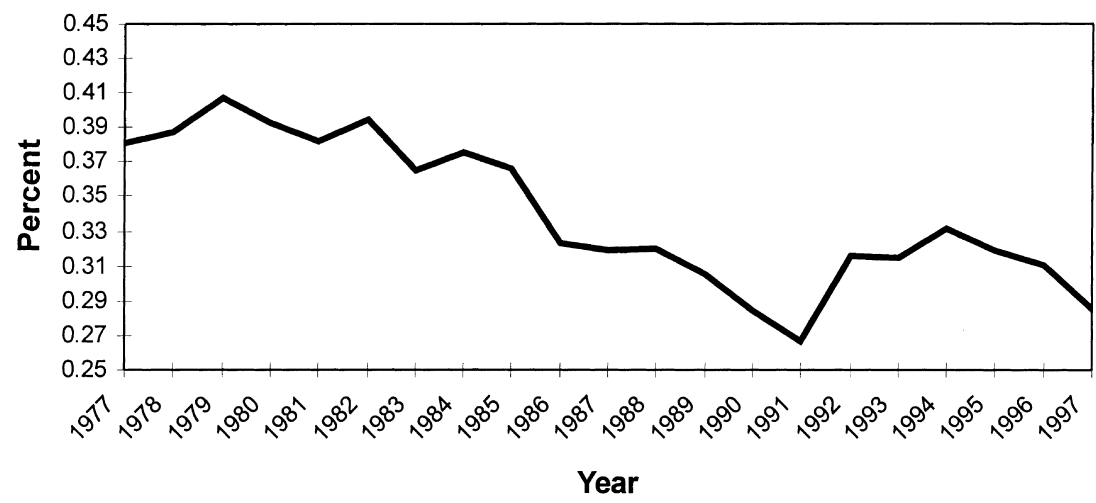

Fig. 9. Net interest income less charge-offs as a percent of financial sector GDP (Source: Survey of Current Business; and Federal Deposit Insurance Company, Historical Statistics on Banking, 1997).

Overall, these changes in what banks do have allowed them to hold their own. As shown in Fig. 11, bank value added as a percentage of financial sector GDP has remained about the same for many years. The difference is that banks have a very different configuration of earnings. ${ }^{5}$ Spread income accounted for about $80 \%$ of bank earnings only a decade ago. Now, most large regional and money center banks earn more than half their income from fees and trading income.

\footnotetext{
${ }^{5}$ Boyd and Gertler (1994) and Kaufman and Mote (1994) have both emphasized this point.
} 


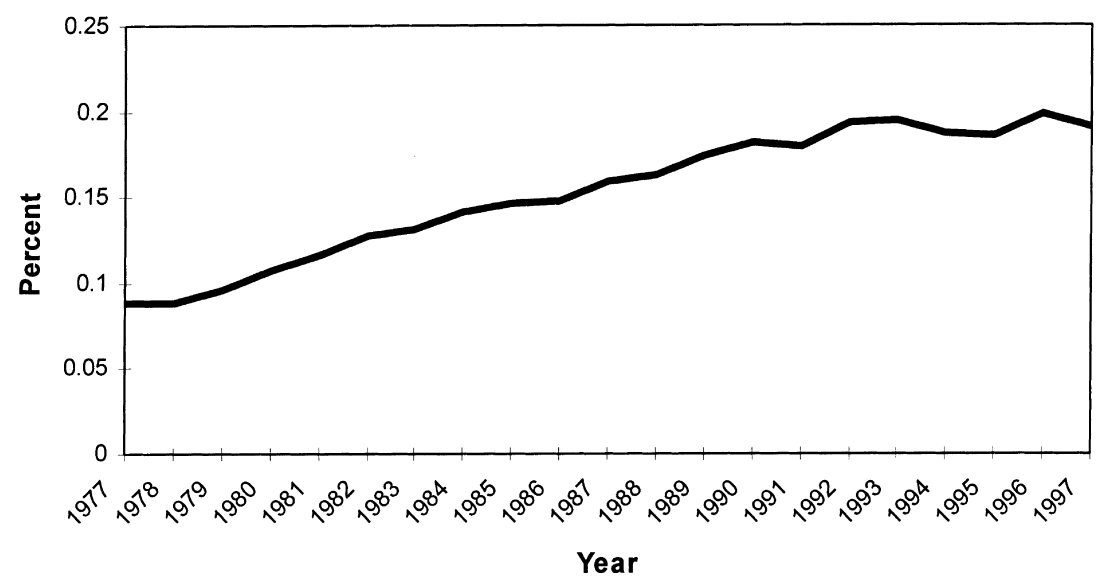

Fig. 10. Noninterest income as a percent of financial sector GDP (Source: Survey of Current Business; and Federal Deposit Insurance Company, Historical Statistics on Banking, 1997).

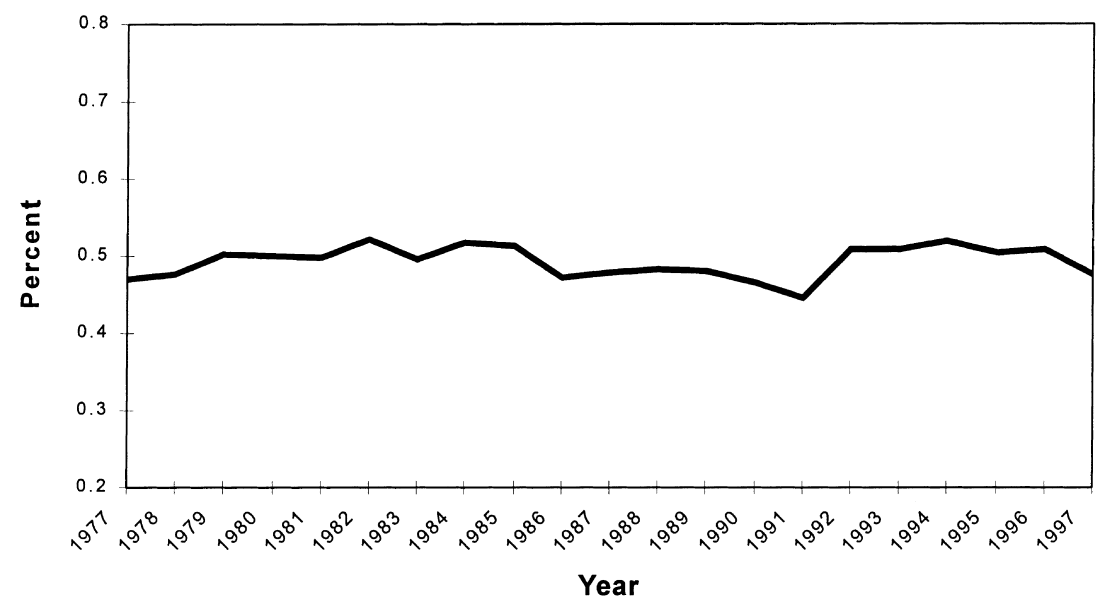

Fig. 11. Bank value added as a percent of financial sector GDP (Source: Survey of Current Business; and Federal Deposit Insurance Company, Historical Statistics on Banking, 1997).

The result is that banks in the US are markedly different than they were even a decade ago. They are no longer the primary source of business and consumer finance. Neither are they the main repository of liquid savings for the financial system. They have managed to restructure their businesses so that they are much less dependent on traditional intermediation income.

This discussion shows that the US financial system has been altered over the years in a very complex way. The changes that have resulted can be summarized as follows: 
- Relative to nonbank intermediaries, the share of assets held by banks is declining.

- Bank assets are not declining relative to total financial assets.

- There is a shift away from directly held assets towards nonbank intermediaries.

- The activities banks engage in have altered significantly. They have moved away from the traditional role of taking deposits and making loans to firms and consumers to fee-producing activities such as trusts, annuities, mutual funds, mortgage banking, insurance brokerage and transactions services.

An important question concerns the extent to which the trends enumerated above are mirrored in other countries. In an important study, Schmidt et al. (1999) have considered how the role of banks has changed in three relevant and important economies, viz., France, Germany and the UK. Fig. 12 shows how the ratio of households' claims on banks as a proportion of their total financial assets has fallen in all three countries, but particularly in France. The same is true of the financial claims of all nonfinancial sectors on banks as shown in Fig. 13.

There is also a change in the way banks operate. Fig. 14 also drawn from Schmidt et al. (1999) shows how the ratio of liabilities of banks to nonbank financial intermediaries compared to total financial liabilities has risen significantly. At the same time, the ratio of securitized financial liabilities of banks to total financial liabilities has risen somewhat for France but only slightly for

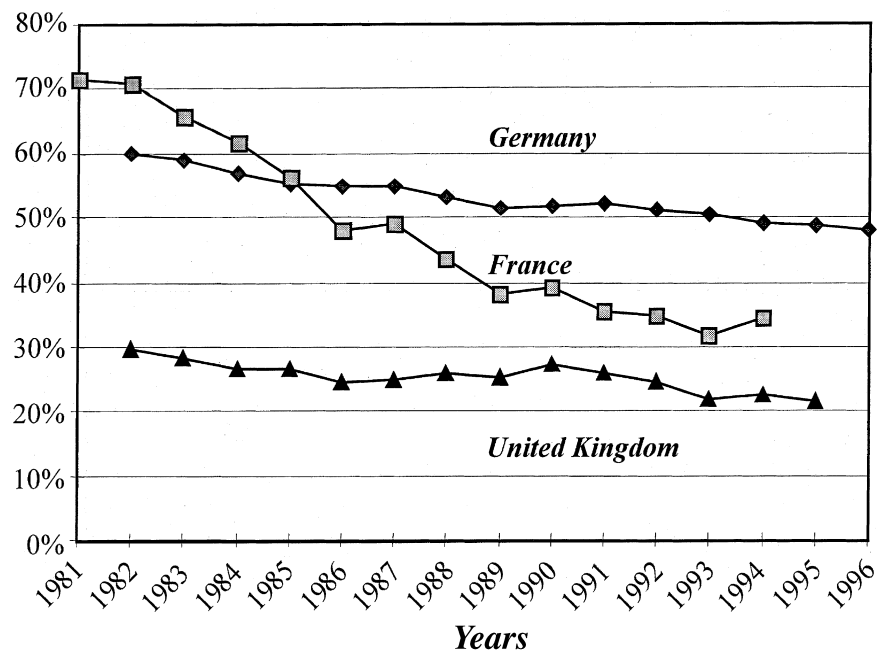

Fig. 12. Asset-IR of Households with Banks = financial claims of HHs on banks/total financial assets of HHs (Source: Schmidt et al., 1999). 


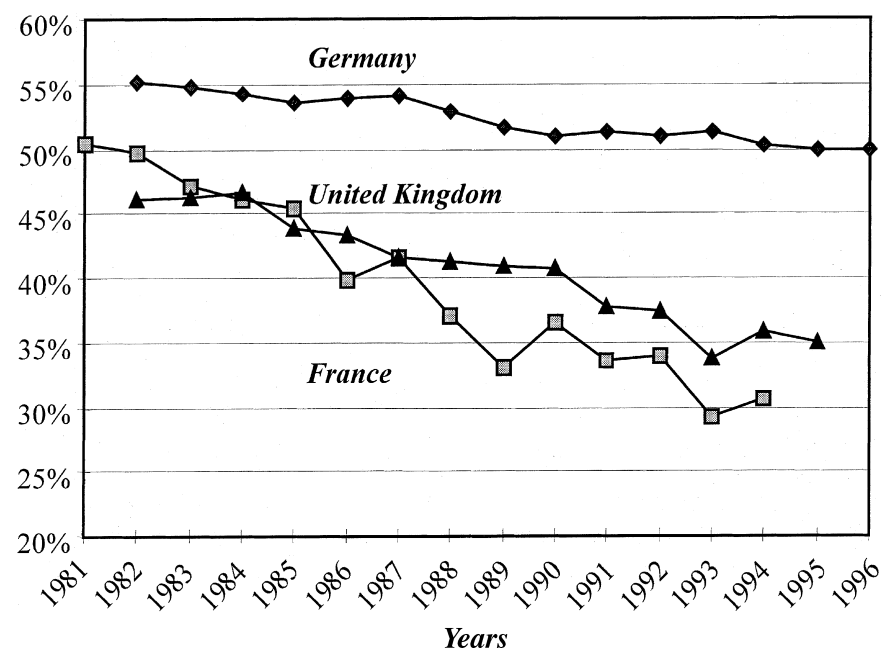

Fig. 13. Asset-IR of all nonfinancial sectors with banks = financial claims of NFS on banks/ total financial assets of NFS (Source: Schmidt et al., 1999).

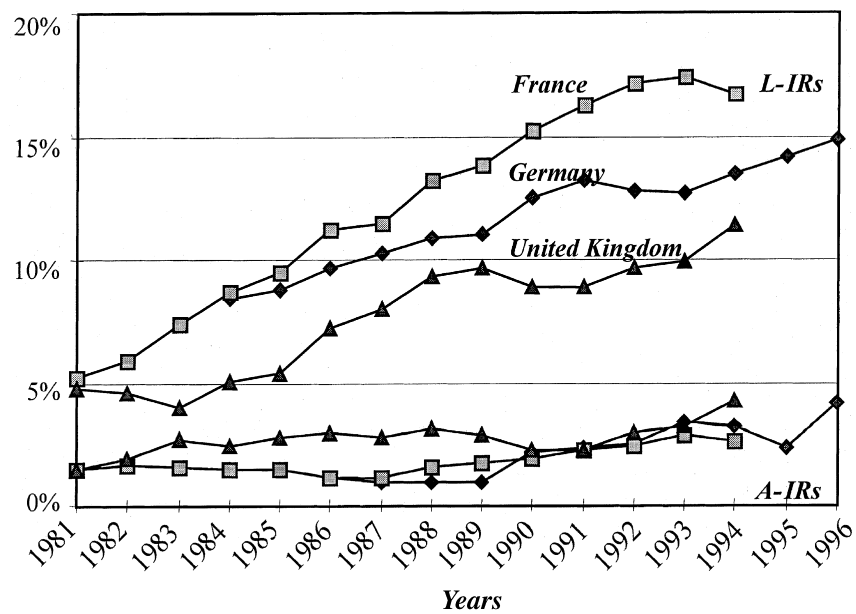

Fig. 14. Liability [Asset]-IR of banks = financial liabilities [assets] of banks of [from] NBFIs/ total financial liabilities [assets] of banks (Source: Schmidt et al., 1999).

Germany and has stayed roughly the same for the UK. The trend observed in the US, therefore, is not unique to that country, and appears to be present in a number of relevant economies. 


\section{Differences in risk borne by households across countries}

AS argue that risk management has become one of the main activities of banks and other financial intermediaries in recent years. The explosive use of derivatives by financial institutions, which they document, is offered as one indicator of the fact that risk management has transformed the role played by institutions in the capital market. In contrast, Scholtens and van Wensveen (1999) argue that risk management has been at the heart of what financial intermediaries do since their origin. Banks have always held risky assets and financed them with relatively safe deposits. The key issue here appears to be how much different is the role of banks in risk management across financial systems and through time. In particular, how do the contracts used by households compare and how do the contracts used by firms differ? Is there evidence that banks and other intermediaries deal with risk differently in the modern financial system typified by the US, compared to other financial systems?

To shed light on this issue, Fig. 15 shows the differences in total assets ultimately owned by households, including both directly and indirectly owned assets, in the five countries. In the US only $19 \%$ is held in the form of cash and cash equivalents which includes bank deposits. A significant proportion, 31\%, is held in the form of relatively safe fixed income assets including domestic and foreign bonds, and loans and mortgages. The largest proportion, 46\%, is held in risky assets including domestic and foreign equity and real estate. The UK is

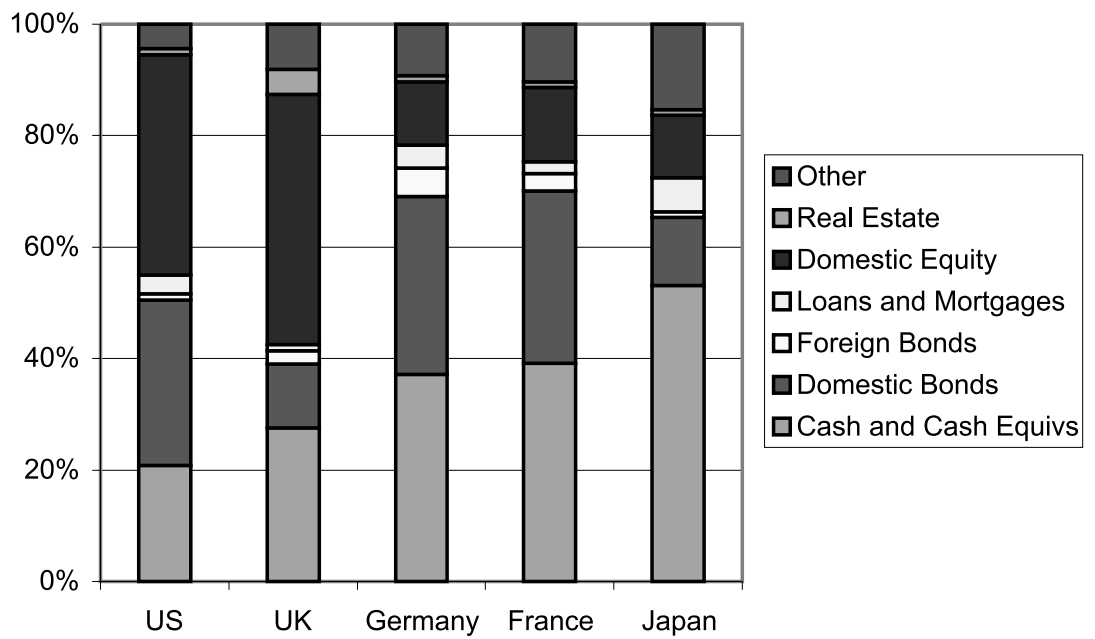

Fig. 15. Portfolio allocation of total financial assets ultimately owned by the household sector ( $\%$ of total) (Source: Miles, 1996, Table 5, p. 22). 
similar with slightly more in cash and cash equivalents at $24 \%$, significantly less in fixed income assets at $13 \%$ and substantially more in risky equity and real estate assets at $52 \%$. In both countries households are exposed to substantial amounts of risk through their holdings of assets.

At the other extreme, households are relatively shielded from risk in Japan, in terms of the makeup of the portfolio of assets they ultimately hold. There, $52 \%$ of assets are held in cash and cash equivalents, 19\% are held in fixed income assets and only $13 \%$ are held in risky equity and real estate. Although not quite as safe as in Japan, households' asset holdings in France and Germany are much safer than in the US and UK. Cash and cash equivalents are lower than Japan at 38\% and 36\%, respectively, while fixed income assets are substantially higher at $33 \%$ and $40 \%$, respectively. The amount of risky assets is comparable to Japan at $16 \%$ for both countries.

It can be seen from these statistics that the proportions of risky assets held by households in the US and UK are much higher than in Japan, France and Germany. This does not necessarily mean that the absolute amount of risk borne by households is greater since more could be invested in financial assets in Japan, France and Germany. Fig. 16(a) shows the gross financial assets ultimately owned by the household sector in the five countries in 1994. In the US the value of financial assets relative to GDP is the highest at 3 but the UK
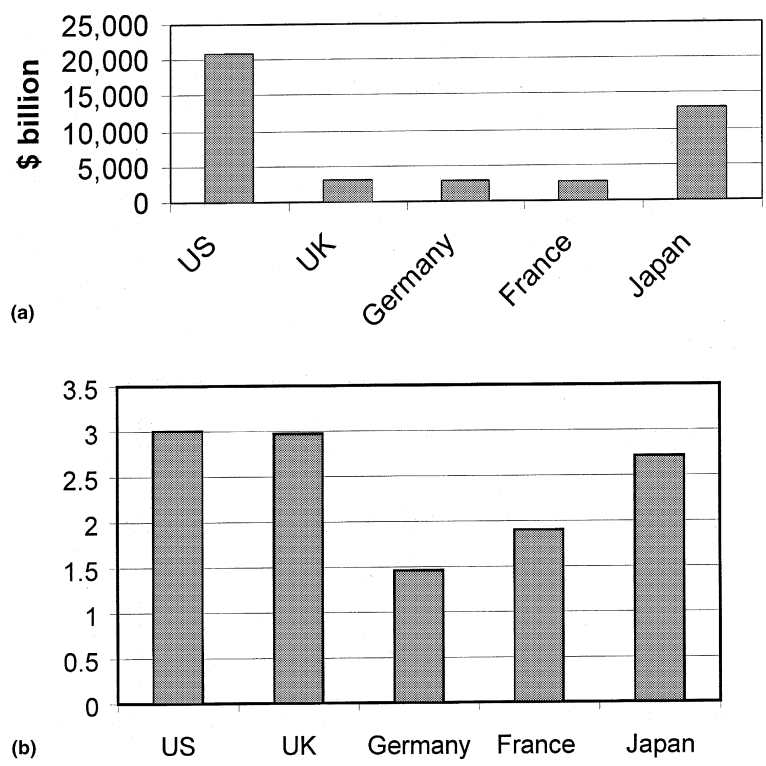

Fig. 16. (a) Total gross financial assets ultimately owned by the household sector (Source: Miles, 1996, Table 4, p. 21) and (b) Total gross financial assets ultimately owned by the household sectorratio value relative to GDP (Source: Miles, 1996, Tables 4, p. 21). 
and Japan are broadly similar. To normalize for the size of each country's GDP, Fig. 16(b) reports financial assets as a percentage of GDP. France and Germany have a significantly lower amount of financial assets with ratios less than 2 for Germany and 1.5 for France. Combining the results illustrated in Figs. 15 and 16 shows that taking into account the amount of wealth held in financial assets increases the differences in the amount of risk borne by households in the different countries, rather than reduces it. Not only do households hold much higher proportions in risky securities in the US and UK, they also hold more financial assets, particularly relative to France and Germany.

How can one explain these differences in the amount of risk households are apparently exposed to in different financial systems? Standard financial theory suggests that the main purpose of financial markets is to improve risk sharing. Financial markets in the US and UK are more developed by most measures than in Japan and France and much more developed than in Germany. How can it be that households are exposed to more risk in the US and UK than in Japan, France and Germany?

Allen and Gale (1997, 1999a) have provided a resolution to this paradox. They point out that traditional financial theory has little to say about hedging nondiversifiable risks. It assumes that the set of assets is given and theory focuses on the efficient sharing of these risks through exchange. For example, the standard diversification argument requires individuals to exchange assets so that each investor holds a relatively small amount of any one risk. Risks will also be traded so that more risk-averse people bear less risk than people who are less risk-averse. This kind of risk sharing is termed cross-sectional risk sharing, because it is achieved through exchanges of risk among individuals at a given point in time. However, importantly, these strategies do not eliminate macroeconomic shocks, which affect all assets in a similar way.

Departing from the traditional approach, Allen and Gale focus on the intertemporal smoothing of risks that cannot be diversified at a given point in time. They argue that such risks can be averaged over time in a way that reduces their impact on individual welfare. One hedging strategy for nondiversifiable risks is intergenerational risk sharing. This spreads the risks associated with a given stock of assets across generations with heterogeneous experiences. Another strategy involves asset accumulation in order to reduce fluctuations in consumption over time. Both are examples of the intertemporal smoothing of asset returns.

Allen and Gale show that the opportunities for engaging in intertemporal smoothing are very different in market-based and bank-based financial systems. They demonstrate that incomplete financial markets may not allow effective intertemporal smoothing, but long-lived financial institutions, such as banks, can allow this, as long they as are not subject to substantial competition from financial markets. In fact, such competition can lead to the unraveling of 
intertemporal smoothing provided by long-lived institutions. This is because in good times individuals would rather opt out of the banking system and invest in the market, thus avoiding the accumulation of reserves which they may not benefit from. Therefore, in the long run intertemporal smoothing by banks is not viable in the presence of direct competition from markets. ${ }^{6}$

This theory provides a framework for thinking about the role of risk management in different financial systems. In bank-based systems such as those in Japan, France and Germany, risk management can be achieved through intertemporal smoothing. Financial intermediaries eliminate risk by investing in short term liquid assets. Other kinds of risk management are relatively less important since cross-sectional risk sharing is correspondingly reduced in importance.

On the other hand, in market-based financial systems intertemporal smoothing by intermediaries is ruled out by competition from financial markets. Here, cross-sectional risk sharing becomes correspondingly more important. As a result individuals or institutions acting on their behalf, need to trade and manage risk in a very different way. They need to ensure that those who are most tolerant of risk end up bearing it. The Allen and Gale theory thus predicts that as financial systems become more market oriented, risk management through the use of derivatives and other similar techniques will become more important. The theory is thus consistent with the fact that risk management is much more important in the US and UK than it is in less market oriented economies such as Japan, France and Germany.

It is also consistent with the rapid increase in the amount of risk management that has been undertaken in recent years. It can be seen from Fig. 2 that the US financial system has changed dramatically in the last century. Until the middle of the 1970s, banks were the dominant form of financial institution. The structure of the financial system was much more like that of Japan, France and Germany, in the sense that banks dominated and markets were less significant. It can be argued that up until then banks were able to engage in intertemporal smoothing. However, the financial innovation that has occurred in the last 25 years changed the form of the financial system from a bank-based one to a market-based one. As the previous sections demonstrated, banks in the US have increasingly had to compete with markets. This has meant that risk management using derivatives markets and so forth has become increasingly important. Thus, the amount US intermediaries have engaged in this type of risk management has increased significantly, because the amount of risk management through intertemporal smoothing has necessarily been reduced.

\footnotetext{
${ }^{6}$ See Petersen and Rajan (1995) for a somewhat different model that investigates smoothing from the lending side.
} 


\section{A dynamic theory of intermediation}

A complete theory of intermediation should explain both static and dynamic aspects of the process. In short it should develop dynamic theories which explain both the need and reality of financial innovation. Here, we give an explanation of the rationale behind these dynamic elements and pressures that favor such innovation without developing a complete theory.

As the analysis in the previous two sections has indicated, we believe that there has been a fundamental shift in the nature of intermediation in the US and also the UK. The amount of risk borne by investors in these countries is different than once was the case, and is also higher than the amount currently borne by households in Japan, France and Germany.

In a traditional bank-based economy, where financial markets are not very significant, the main way in which banks deal with risk is through intertemporal smoothing. They acquire a "buffer" of short-term liquid assets when times are good and run this buffer down when times are bad. As a result of this buffer, households that hold most of their assets in bank accounts and other fixed income assets are to a large extent shielded from risk and are able to have smooth consumption streams.

When financial markets develop they provide competition to banks which makes the intertemporal smoothing they undertake increasingly more difficult. Financial markets allow high returns in good times and there is an incentive for individual investors to withdraw their funds from banks and put them in markets instead. In order to survive the banks must essentially compete with the markets and cease offering intertemporal smoothing.

The data we presented in Section 2 showed how this fundamental change has altered the business that banks undertake in the US. As we documented there, banks have been forced to be more entrepreneurial and to innovate in order to survive. They have entered new markets and developed new products. Their traditional role of taking deposits and making loans has been steadily shrinking. Despite regulation designed to ensure they limit their activities to commercial banking, they have been able to increasingly skirt these regulations and lobby for changes. This has allowed them to enter the underwriting, distribution, asset management, and insurance businesses, as well as develop new products. ${ }^{7}$ They have succeeded in replacing their traditional business with fee-producing activities, as Fig. 10 illustrated. This has been accomplished by institutions shifting their role from principal to agent in many transactions.

This move is quite consistent with the shift from intertemporal smoothing to cross-sectional risk sharing outlined in Section 3. The role of surviving intermediaries has become one in which they have increasingly facilitated risk

\footnotetext{
${ }^{7}$ See Santomero and Babbel (1997), Chapter 24, for a detailed discussion of this process.
} 
transfer and allocate it to those most able to bear it. Achieving this new role requires considerable change and innovation on the part of individual institutions and individual bankers as well.

In recent years a considerable literature on financial innovation has developed (see, e.g., Allen and Gale (1994) and Duffie and Rahi (1995) for overviews). However, this literature has been concerned mainly with the innovation of securities in financial markets, rather than understanding the role of intermediaries in the process, or the dynamics of change within the institutions themselves. More needs to be done to better understand this challenge.

In AS we suggested that participation costs are important to understanding modern intermediaries and their new role. We believe that lowering participation costs would appear to be an important motivation for much of the innovation that has taken place in financial services. It is simply too costly for individuals to directly manage risk using modern techniques.

A key point to appreciate, however, is the precise meaning of participation cost in this context. One interpretation of participation cost is that it is simply the time involved in making financial decisions. AS point out that the opportunity cost of people's time, particularly for many professionals, has increased significantly in the last 15 years. Scholtens and van Wensveen (1999) have argued that wages in fact have been flat in the US during this period. While true in the aggregate, this is not the case for professionals who undertake the majority of savings, because income inequality has increased over this same period. More importantly, though, this is only part of the costs of participating in markets.

A much broader notion of participation costs is required to understand the kinds of innovation that are occurring. The degree of sophistication and specialization required to undertake complex risk trading and risk management operations is very high. It is the problems associated with acquiring and using this expertise that are really at the core of what we mean by participation costs.

Much of what modern intermediaries do is to interface between individuals and increasingly complex financial markets. In order to do this effectively intermediaries must make their products relatively simple to understand, even if they are not simple to implement. Alternatively, they must develop a relationship based on trust with the investors they serve. Allen and Gale (1999b) have argued that the complex problems involved in delegating decisions to an intermediary (agent), when the investor (principal) does not fully understand the nature of the problem being solved, can be overcome with long term relationships. Financial markets and financial intermediaries then have a symbiotic relationship. Each is necessary to the other. Without intermediaries, the informational barriers to participation would prevent investors from reaping the benefits of new markets, and the markets themselves might not survive. At the same time, financial markets allow intermediaries to hedge cross-sectional risks more effectively than they previously could. 
Viewed in this context innovation becomes central to the theory of intermediation. Banks and other intermediaries need to develop new ways to lower participation costs. This allows everybody to benefit from improved crosssectional risk sharing. Merton and Bodie (1995) have termed this the "financial innovation spiral".

\section{Concluding remarks}

The world financial system has changed significantly in recent decades. In the US, banks and many other types of intermediaries have moved away from their traditional role of taking deposits and making loans. Although their share of intermediated funds has fallen they have not shrunk relative to GDP, and they remain an important part of the financial system. They have achieved this by moving away from simple balance sheet intermediation toward feeproducing activities.

A comparison of the modern US financial system with other financial systems shows broadly similar trends but significantly distinct operating models. Broadly speaking, the US and UK appear most similar, with France and Japan moving toward the Anglo-Saxon model, and Germany still quite far away.

One result is that risk is borne differently in these economies, as can be seen by the aggregate portfolio composition of households. This shows that US household allocations are similar to the UK but quite different from Japan, France and Germany. In the US and UK individuals hold significantly more risky assets, and are exposed to more risk than in Japan, France and Germany.

We argued that this difference could be understood using the framework of Allen and Gale (1997, 1999a). In the absence of significant competition from financial markets as in Japan, France and Germany, intermediaries are able to eliminate risk by intertemporal smoothing. They build up reserves of short term liquid assets when returns are high and run them down when they are low. In contrast, in the US and UK where financial markets are more developed and accessible, intermediaries are unable to engage in such intertemporal smoothing. If they were to do this, investors would withdraw their funds completely and invest them in markets instead. Here, risk must be dealt with through cross-sectional risk sharing. As a result, risk management takes the form of investing in derivatives and other similar kinds of strategy, rather than carrying reserves over from one period to another.

This theory implies that the significant development of financial markets in the US over the past 25 years is consistent with the transformation of the banking industry there. Prior to that time financial markets provided much less competition to intermediaries, and banks would have been able to manage risk by building buffers of liquid reserves and intertemporally smoothing. However, as competition from financial markets increased this was no longer possible 
and intermediaries had to manage risk in different ways. The increase in the importance of cross-sectional risk sharing led to the use of derivatives and other similar techniques for risk management. These developments forced banks to move away from their traditional borrowing and lending activities and develop new fee-based sources of revenue. They have been sufficiently entrepreneurial and innovative that they have managed to hold their own.

A number of unresolved puzzles or at least open issues remain. In Section 3 we discussed the portfolio holdings of households in different countries. We pointed out that there are significant differences between the US and UK on one hand, and Japan, France and Germany on the other. However, there is a parallel literature that addresses financial sector differences in terms of the financing of firms. There are a number of studies of this, including the work of Mayer (1988, 1990), Bertero (1994), Rajan and Zingales (1995), and Corbett and Jenkinson (1996). The perspective gained from this literature is much less clear than the results reported here.

Data issues appear to be a large part of the problem. Two sources of information have been used in the sources of corporate financing literature. One uses accounting and market data, and focuses on the capital structure of firms (see, e.g., Rajan and Zingales (1995) for an excellent example of this type of study). There are a number of problems with this type of approach, not the least of which is to reconcile accounting data from different countries. In addition, it does not distinguish between internal and external finance, which for many topics concerned with financial systems is important. The alternative method, which has been widely adopted, is to analyze sources and uses of funds data from national accounts. This approach was pioneered by Mayer (1988, 1990) and has subsequently been used by Bertero (1994) and Corbett and Jenkinson (1996). These studies have the advantage that the data sets used are reasonably comparable and internal and external finance can be compared.

These studies, based on sources and uses of funds statements, look at the net financing from various sources and work out how investment was funded. Table 1 from Bertero (1994) for France, and Corbett and Jenkinson (1996) for

Table 1

Unweighted average gross financing of nonfinancial enterprises 1970-1989 (\% of total)

\begin{tabular}{llcccc}
\hline & US & UK & Japan & France & Germany \\
\hline Internal & 91.3 & 97.3 & 69.3 & 60.6 & 80.6 \\
Bank finance & 16.6 & 19.5 & 30.5 & 40.6 & 11 \\
Bonds & 17.1 & 3.5 & 4.7 & 1.3 & -0.6 \\
New equity & -8.8 & -10.4 & 3.7 & 6 & 0.9 \\
Trade credit & -3.7 & -1.4 & -8.1 & -2.8 & -1.9 \\
Capital transfers & - & 2.5 & - & 1.9 & 8.5 \\
Other & -3.8 & -2.9 & -0.1 & -6.5 & 1.5 \\
Statistical adjustment & -8.7 & -8 & 0 & 2.5 & 0
\end{tabular}

Source: Bertero (1994) and Corbett and Jenkinson (1996). 
the other countries, gives the results of such a study for the period 1970-1989. It can be seen that internal finance is by far the most important source of funds by far in all countries. Bank finance is moderately important in most countries but particularly in Japan and France. Bond finance is only important in the US, and equity finance is either unimportant or negative (i.e., shares are being repurchased in aggregate) in all countries.

How can these results be reconciled with the data on composition of household portfolios? One would expect that in the long run household portfolios would reflect the financing patterns of firms. Since internal finance accrues to equity holders one might expect that equity would be much more important, particularly in Japan, France and Germany. There are of course many differences in the two data sets. For example, household portfolios consist of financial assets and exclude privately held firms, whereas the sources and uses of funds data include all firms. Nevertheless, it seems unlikely that such differences could cause such huge discrepancies.

There is no widely accepted resolution to this apparent discrepancy. However, in a recent paper Hackethal and Schmidt (1999) argue that it results from an apparently innocuous assumption in the methodology used in these studies. This is the assumption that the proceeds from new bank finance are first used to repay old loans and then are used for funding investment. It is similar for other sources of funds such as bonds and equity. The only exception is internal finance where there is nothing to be repaid. This distorts the measurement of the sources of finance toward internal finance and makes it seem more important than it is. When they correct for this distortion they find figures much more in line with the portfolio data reported here.

Another puzzle relates to the sheer size of risk trading activity in the financial markets, as captured by open positions and notional volumes of foreign exchange and derivative trades. It seems always incredulous to assert that such large volumes are necessary to merely transfer risk between interested ultimate parties. However, here too measurement problems may be at the heart of the controversy. The way in which volume is measured in standardized markets may be the real problem. It should be remembered that risk trading is a dynamic activity associated with the need of at least one party to alter the state contingent return to a financial transaction. As circumstances change, offsetting trades may be conducted or a number of alternative subsequent trades may be added to further alter the financial returns facing a counterparty. Over time many of these trades are offsetting, with net positions only a small fraction of the total. Yet, most of these risk trading activities are conducted in the broker-dealer market, rather than on formal exchanges. For example, most foreign exchange, swaps and credit derivatives are broker-dealer transactions.

This fact is important when it comes to measuring the overall volume of activity, as broker-dealer transactions are measured in gross notional amounts outstanding. In the case of exchange transactions the results are netted and 
only net positions are reported. This has led to an overstatement of overall risk trading and a gross overstatement of true outstanding positions. Whether a more accurate measure of volumes will satisfy those that contend that trading volume exceeds simple risk management needs is still open to question. Our only point here is that the current measures clearly overstate the activity in question.

\section{References}

Allen, F., Gale, D., 1994. Financial Innovation and Risk Sharing. MIT Press, Cambridge, MA.

Allen, F., Gale, D., 1997. Financial markets, intermediaries and intertemporal smoothing. Journal of Political Economy 105, 523-546.

Allen, F., Gale, D., 1999a. Comparing Financial Systems. MIT Press, Cambridge, MA.

Allen, F., Gale, D., 1999b. Innovations in financial services, relationships and risk sharing. Management Science, forthcoming.

Allen, F., Santomero, A.M., 1997. The theory of financial intermediation. Journal of Banking and Finance 21, 1461-1485.

Bank for International Settlements (BIS), 1998. Statistics on Payment Systems in the Group of Ten Countries, Basle.

Barth, J.R., Nolle, D.E., Rice, T.N., 1997. Commercial banking structure, regulation, and performance: an international comparison, Working Paper. Office of the Comptroller of the Currency, Washington, DC.

Bertero, E., 1994. The banking system, financial markets and capital structure: Some new evidence from France. Oxford Review of Economic Policy 10, 68-78.

Bhattacharya, S., Thakor, A.V., 1993. Contemporary banking theory. Journal of Financial Intermediation 3 (1), 2-50.

Boyd, J., Gertler, M., 1994. Are banks dead? Or are the reports greatly exaggerated? Federal Reserve Bank of Minneapolis, Quarterly Review, Summer.

Corbett, J., Jenkinson, T., 1996. The financing of industry, 1970-1989: An international comparison. Journal of the Japanese and International Economies 10, 71-96.

Dewatripont, M., Tirole, J., 1994. The Prudential Regulation of Banks. MIT Press, Cambridge, MA.

Duffie, D., Rahi, R., 1995. Financial market innovation and security design: An introduction. Journal of Economic Theory 65, 1-42.

Freixas, X., Rochet, J.-C., 1997. Microeconomics of Banking. MIT Press, Cambridge, MA.

Hackethal, A., Schmidt, R.H., 1999. Financing patterns: measurement concepts and empirical results. Working paper, University of Frankfurt.

Kaufman, G.G., Mote, L.R., 1994. Is banking a declining industry? A historical perspective. Federal Reserve Bank of Chicago: Economic Perspectives, May/June, 2-21.

Mayer, C., 1988. New issues in corporate finance. European Economic Review 32, 1167-1188.

Mayer, C., 1990. Financial systems, corporate finance, and economic development. In: Hubbard, R.G. (Ed.), Asymmetric Information, Corporate Finance and Investment. University of Chicago Press, Chicago, IL, pp. 307-332.

Merton, R.C., Bodie, Z., 1995. A conceptual framework for analyzing the financial environment. In: Crane, D.B., et al. (Eds.), The Global Financial System: A Functional Perspective, Harvard Business School Press, Boston, MA.

Miles, D., 1996. The future of savings and wealth accumulation: Differences within the developed economies. Global Securities Research and Economics Group, Merrill Lynch, London. 
Petersen, M.A., Rajan, R.G., 1995. The effect of credit market competition on lending relationships. Quarterly Journal of Economics 110 (2), 407-443.

Rajan, R.G., Zingales, L., 1995. What do we know about capital structure? Some evidence from international data. Journal of Finance 50, 1421-1460.

Santomero, A.M., 1984. Modelling the banking firm. Journal of Money, Credit and Banking 16 (4), 576-602.

Santomero, A.M., Babbel, D., 1997. Financial Markets, Instruments and Institutions. Irwin, Chicago, IL.

Santomero, A.M., Hoffman, P., 1998. Life insurance firms in the retirement market: Is the news all bad? Journal of the American Society of CLU and ChFC.

Schmidt, R.H., Hackethal, A., Tyrell, M., 1999. Disintermediation and the role of banks in Europe: An international comparison. Journal of Financial Intermediation 8, 36-67.

Scholtens, B., van Wensveen, D., 1999. A critique on the theory of financial intermediation. Journal of Banking and Finance, 24 (8), 1243-1251. 